\title{
Benign Vascular Neoplasm
}

National Cancer Institute

\section{Source}

National Cancer Institute. Benign Vascular Neoplasm. NCI Thesaurus. Code C7389.

A benign neoplasm arising from vascular tissue usually of the skin. It is characterized by the presence of vascular channel formation and endothelial cells. 